\title{
Women Consciousness Exploration in Jane Austen and Her Works
}

\author{
Xiaojun $\mathrm{He}^{1}$, Lina Liao ${ }^{2}$ \\ ${ }^{1}$ School of Foreign Languages, Leshan Normal University, China \\ ${ }^{2}$ Guanglin Primary School, Guangling, Chengdu, China \\ Correspondence: Xiaojun He, School of Foreign Languages, Leshan Normal University, Leshan, Sichuan, China. Tel: \\ 86-139-8137-6137.
}

Received: September 14, 2015 Accepted: September 28, $2015 \quad$ Online Published: September 30, 2015

doi:10.11114/jets.v3i6.1125 URL: http://dx.doi.org/10.11114/jets.v3i6.1125

\begin{abstract}
Jane Austen is one of the greatest realistic novelists in the English literaturein19th century. Austen is contrary to consciousness of man centrism and traditional values of masculine writers before her time. All her 6 novels concerns with love and marriage, they truthfully reflect women life of her age, reveals her feminine consciousness and profound implication.
\end{abstract}

Keywords: Jane Austen, Cinderella complex, women independence consciousness

\section{Introduction}

Jane Austen (1775-1817) is the most brilliant star among the British novelists. She was brought up in an intelligent but restricted environment. As we all know, it is not until the second half of the 18th century that women novelists began to appear in England. She is an English writer, who first gave the novel its modern character through the treatment of everyday life. She was just such a great woman writer in this period. She brought the English novel to its maturity and her satirical fictions marked the transition from the 18th-century neoclassicism to the 19th-century romanticism in the English literature.

Although Austen was widely read in her lifetime, she published her works anonymously. The most urgent preoccupation of her bright, young heroines is courtship and finally marriage. Austen herself never married. Jane Austen wrote six complete novels during her lifetime: Sense and Sensibility, Pride and Prejudice, Mansfield Park, Emma, Northanger Abbey and Persuasion. In these six novels, she well described most of the unmarried girls' pursuits and ideas about marriage in her own time. She considered it her duty to express in her works a discriminated and serious criticism of life, and to expose the follies and illusions of mankind. Of course, these descriptions have brought her a great fame as well as some criticisms.

In my opinion, Jane Austen was a feminist writer. It seemed that Jane Austen was not as radical as the early feminists who took part in the violent movement to struggle for their rights. Jane Austen maintained that women should have the same rights and opportunities as men. In her novels, many women characters were not inferior to men. Women deserved to share the equal rights with men. At this point, Jane Austen could stand with some contemporary feminists.

\section{Cinderella Complex}

Jane Austen's 6 novels all described love and marriage, so we can see how important the love and marriage is in her mind. She make her dream come true just through the Cinderella stories in the novels, for she can't get the nice love which she described.

\subsection{The Cinderella Complex in Pride and Prejudice}

Darcy and Elizabeth's love in Pride and Prejudice is the typical one on the ideal Prince and Cinderella's love. In this novel, Elizabeth is a gentleman daughter who's wealth would all e deprive. On the other side, Darcy is the man has the high position, the highest rule class in the English society, the offspring of the peer. He has a hereditary manor, lots of lands. His family circumstances is very rich. Besides, he's handsome and distinguished. He is the perfect prince for all the heroines in Austen's novels. The combine of Elizabeth and Darcy is a kind of overfly actually. 


\subsection{The Cinderella Complex in Emma}

The destiny of Cinderella in Emma, is be fall to another heroine Jane Fairfax .She is a orphan and parents passed away early, and grown up in a environment of depend on another person for support. She is born of beautiful. She and Frank Churchill were in deep love with each other, although they didn't dare declare it, they still married at the end the story and live a happy life.

\subsection{The Cinderella Complex in Persuasion}

Anne is the Cinderella in Persuasion, she isn't respected in the family, and always ignored by others. Her position in family even inferior to her family's dependant. The author also arranged her a unexpectedly perfect marriage.

Through the marriage ,the Cinderella's position in the novels are all get advance, and the destinies get changed. This is the long-cherished wish Jane Austen herself couldn't achieved. At the same time, it is the felicity which the beautiful perspicacity, grace, and kind hearted Cinderella be supposed to obtain. Without wealth, love could be the sacrifice of substance in the paternity society. In order to search for the balance of the both Jane Austen created the Cinderella condition for the heroines to express her wish of bumper both on love and substance.

\section{Women Independence Consciousness}

Jane Austen's literature creation days was during the deep paternity society system time. Jane observed the importance of the economic factor to the women social status by her sharp eyes. She told people that the nature of capitalist marriage was the combination of exchange of money and benefits. In a word, in marriage, no money will not do. It was economy and figures that decided people's life, fate and their marriage. It is very common that a woman can not marry because of her family responsibilities. But She would never seek marriage for the physical wealth as a kind of extrication. This independence consciousness was focus on the Elizabeth in Pride and Prejudice.

\subsection{Charlotte's Marriage in Pride and Prejudice.}

Elizabeth's friend Charlotte take marriage as a aim all the time for not be an old virgin. She has no distinction glorious family, beautiful color and love story while she is over 27 years old. She wanted a home. In the marriage market Charlotte had little advantage, she must marry some one. Husbands were hard to find for a woman like her, once she found one she must catch him immediately. So, when Elizabeth refuse the foolish Collins's proposal whom inherited his father's fortune and was promoted by Lady Catherine, Charlotte amuse Collins on her own initiative, they finished the marriage at the highest speed, then give her a comfortable home. She ignored husband's gaffe before his friends and don't care her marriage is base on little love, she does her best to avoid Collins as much as possible. At that time, hundreds of women married men without being attracted to them or greatly repelled by them, and learned to love them after marriage, instead of before. That makes people very uneasy and they felt embarrassed for them. For Elizabeth and any modern women, they couldn't imagine this kind of marriage even accept it. In Elizabeth's eyes, money and benefit are not important than true love. Marriage couldn't only based on the physical elements. An ideal marriage must fulfill the needs of physical, emotion and morality rationally.

\subsection{Elizabeth's Marriage in Pride and Prejudice.}

Elizabeth's character is presented mainly through contrast with other female characters. In hunting for a husband, she is distanced from her own sisters who are either too passive or too shameless and mindless in society of men. However, intelligent and wise Elizabeth in the face of Darcy's first proposal, she refuse it. Because at that time, he didn't forget the worldly rank conception, and the pride in his behavior. The scorn to her family and relations in his first proposal really irritated Elizabeth, thus she very revolt against Darcy. She thought that Darcy is offend and humiliate her actually. She couldn't accept such marriage in spite of reverence. Her judgment of Darcy was absolutely from her real feeling, not considered the physical change take from his property and position. Elizabeth was no more the male's foil and dependency, on contrary, she showed high self-confidence and independence in intelligence and spirit. Elizabeth could be the author's mouthpiece. Jane Austen never conceal her favor to Elizabeth, because she depend on her female personality ideal and brand new women consciousness on this character.

\section{Jane Austen New Ideals on Women}

\subsection{Women Intelligence and Rationality Compared to Man}

In Jane Austen's novels, she shows her unique point of view on woman different from the common ideas. At her time, the dominant idea on woman was very low: second class, and lower sex. Jane Austen disagrees with them. Jane Austen wrote the novels on the assumption that women were inherently as intelligent and rational as $\mathrm{m}$ en were. In the marriage market into which her heroines usually enter, the woman is as likely to be the instructor as the man is. Whereas in Emma it is Mr. Knightley who teaches Emma. But Darcy, in Pride and Prejudice, whom Jane Austen describes as clever and the ideal gentleman, learns as much from Elizabeth Bennet as she does from him. Also does in the Sense and 
Sensibility. Elinor experiences sufferings as much as man do and deals with them like a man. Equal with her belief of intelligent is Jane Austen's belief that intellectual abilities areas desirable in the woman as in the man. This kind of female worth informs the treatment of some of the main female characters in Pride and Prejudice. Jane Bennet and Miss Bingley both have qualities, which are regarded as marks of feminine excellence in an age, which advise women to conceal any mental accomplishments. Jane has a benevolent attitude to wards the world, and hers is a soft and yielding temperament; Miss Bingley is accomplished, elegant and physically attractive. Yet neither is judged the equal of Elizabeth Bennet be cause they lack her 'quickness of observation' and 'judgment' This standard of excellence is made explicit by Darcy, who comments that while a woman should cultivate accomplishments such as 'music, singing, drawing, dancing and the modem languages...to all this she must add something more substantial, in the improvement of the mind by extensive reading'.(Pride and Prejudice ch. viii) Girls should not be accused of such kind of fault, because it is the society that educates them like that. Bad education only gives girls such kind of accomplishment.

\subsection{The Importance of Girls Education}

"Improvement of mind" is in fact so important to Jane Austen that in considering how girls should be educated she also shows her ideas. In spite of the physical attraction, almost all of her heroines are deficient in the superficial virtues. Elizabeth Ben net and Emma Woodhouse both neglect their piano practice and hence are no more than moderate performers. Yet none of them is called upon to improve in these areas. Their education is complete so far as Jane Austen is concerned once they have corrected certain failings in judgment and/or feeling. The education in personality is more than the education of appearance. The improvement of mind should be the final purpose of education

\subsection{The Fault of Over-meekness}

Jane Austen is hostile to the view that meekness is the major feminine so far as she is concerned, Elizabeth Bennet behaves far more admirable when she ignores trample showing across muddy fields to visit the sick lane. Jane almost misses her true love by not her love to Bingley, and it is Elizabeth's courageous action that makes Darcy realize his mistakes. Elizabeth refused the marriage proposal by Mr. Collins anger. At that time a girl in her position without dowry, rarely can in spite of her mother's do such kind of thing, because nobody is sure whether she has another marriage proposal or not, otherwise she may stay at home forever. But Elizabeth does refuse the proposal and Jane Austen gives her a good destiny in the end of the novel in order to show her great appraisal of Elizabeth. By this way, Jane Austen tries to argue that meekness is a fault rather than a virtue. Meekness can destroy a woman's whole life.

\subsection{The Important of Household Management for Women}

The implications of household management, the other main aspect of the woman's domestic role, are also stressed. Those who order their houses well are securing the health of the nation, while those who neglect them are damaging it .Every housewife has a crucial role to play in preserving the house. That also explains the reason why Jane reserves some of her sharpest irony in Sense and Sensibility for Mrs. Dashwood's deficiencies as a household manager: "In the mean time, till all these alternations could be made from the savings of an income of five hundred a- year by a woman who never saved in her life, they were wise enough to be contented with the house as it was" Sense and Sensibility chapter VIIII.) Were it not that Elinor introduces some methods into her dealings Mrs.Dashwood would be guilty of damaging the fabric of English society, and thus deserves to suffer the lash of Jane Austen's tongue. Though Mrs. Bennet's household management ability does not mentioned, her ability can not be good. In Emma, Emma manages the home.

To deal with this paradox between lower sex and house hold management, for Jane Austen the restrictions imposed on the woman's social role do not diminish its importance. Rather, basing on her case on contemporary conservative philosophy, she argues that those who control manners and the home have a crucial role to play.

\section{Jane Austen's Women Consciousness' Value in the English Literature}

\subsection{The Value Orientation of Jane Austen's Female Consciousness}

The value orientation of Jane Austen's female consciousness first showed at her establishment on the female sex characteristic. For Austen, the female not only has a various characteristics like beauty, kind-hearted, tender that should have in male society, and she has weakness and sense and intelligence in the meantime. Her work mainly focus on the young, single female. They all inherit traditional virtue, sense and acquire the happiness in the end.

Unlike former female writers, Jane Austen specially emphasizes the female's cultural awareness in life. She believe this would make female more impressive, and it is an important part of female value. With such self-cultivation, women could face the various challenges in life and love. Then female could not lose personality and dignity as a person, get the respect of male, win the love finally. In Jane Austen's eyes, self-cultivation, self-respect are the center part of the female value. 
The value orientation of Jane Austen's female consciousness is also expressed in the definite of the women status. Though she make every effort to promote the female's intelligence and reasonableness, but she still thinks that the female's function lies in a family. The end-result of the female in her works are marriage and family. No matter sexual equality and or a character to expand, all be limited by a family. The women job are concern with sons and daughters' education personality., guide servant and insure a house is comfortable and help husband to build up various social interaction. But she also thinks that the women need high intelligence to bear comparison with the male, then they can exert these responsibility. Then can also make them not lose the position ,status in the process which is full of a test This expresses that the Jane Austen admits the differ of the male and the female in the society the female's social role that tradition give, also affirmed the importance of this role. Although these viewpoints class limit of the middle class women, they emerged a new kind of consciousness of female fight for the equality: Sexual equality should start from the family. The female's functions in support family, good traditions and morality as well as male in society..

At that time, women be just the predominate of male, and is limited. Many women consciousness are come from male. Jane Austen not only emerge the true society, but also forecast the social development of women consciousness in her sharp eyes, and let the description and analysis of male as the foil of the females' in her novels.

Through the analysis of the value orientation of Jane Austen's female consciousness, we can see that she focus on female subject consciousness from female aspect. The issues from her works are the sense and intelligence when female wake up to face true society, their seek for the social status. Jane told the readers the lovely and independent are come from 'the understanding of one's own value. As a women who dare to challenge to the traditional views, Jane Austen fulfilled her new ideal of women consciousness in her works.

\subsection{Jane Austen Creation Environment}

In the English literary world in 18 century, more and more women have take up novel writing. They often unconsciously written on the position of male simulate male's creation, because the paternity culture value view as a kind of cultural phenomena is exist in human's normal cultural psychology when women take their pens. The male authority always impact on them. It is difficult to write their own literature. Because women position in the first half of the 19th century was very low. And that time feminism was not paid attention to common people. Practically everyone believed that men were the superior sex. British women had few rights, few opportunities and only a few people realized the bad situation of women. They are limited not only by the family and social custom, but also the books they read. They find it is difficult to break away of this limit. But when the women writers took on their pens, they may take the power of speaking and speak out their understanding of the new women consciousness and the negative to the women value in paternity culture.

\subsection{The Value of Jane Austen Women Consciousness in the English Literature History}

In Jane Austen's time, women had a great deal of unhappiness and frustration that they must face. After Jane Austen, many female novelists came forth in England in order to escape from such kind of situation. They all tried to cry for women, show their women consciousness and critic the social reality. They have important function in the form of novel. It has been calculated that women wrote about 20percent of all books published in the 19th century. This couldn't be the parted with Jane Austen's impact. She could be the forerunner for here contribution to setting up a female writing tradition. But it didn't means women went into the central part of the literature creation. Even in nowadays, in the more enlightened countries, we can't say the women already get complete release, or get rid of the worth standard of paternity. Austen changes women inferior position of being observed in male works by presenting her heroines for the first time as active speakers of true feelings of their own, and she wrote at a time of stress. So we show our more respect for Jane Austen who search women self consciousness hardly in the paternity.

\section{Conclusion}

Jane Austen's position and the importance of her works cannot be neglected in the history of English literature. Her fictions could be regarded as feminist works that challenge the patriarchy.. I reflected the relationship between woman and man in Austen's novels, analyzing Austen's attitude to marriage, especially women right to choose, emphasizing the woman. Austen paid serious attention to women felicity and independence, and rebelled against the patriarchy rather than maintaining it. In this respect, Austen should be looked upon as a feminist writer.

In a word, Jane Austen is a genius that appeals to any generation. I believe there is still much research to do with Jane Austen the person as well as her great novels.

\section{References}

Austen-Leigh, J. E. (1985). A Memoir of Jane Austen. London: Penguin Books.

Claire, T. (1997). Jane Austen: A Life (Alfred A. Knopf, 1997). 
Deirdre, L. F. (2004). Jane Austen: A Family Record (Cambridge University Press, 2004).

Jan, F. (1991). Jane Austen: A Literary Life (Macmillan Press, 1991).

Tucker, G. H. (1994). Jane Austen the Woman. New York : S t. Martin's Press, 1994.

\section{$(\infty)$ EY}

This work is licensed under a Creative Commons Attribution 3.0 License. 